\title{
Risk, estrogens - and a poem
}

On p. 321 of this issue, the Swedish sociologist Ingar Palmlund presents in brief her study in societal risk evaluation of estrogen use. The paper is based on the Ph.D. awarded to her in the summer of 1990 by Clark University for her thesis; the latter is distributed by UMI, 300 N. Zeeb Road, Ann Arbor, MI 48106, U.S.A.

It must be highly unusual for the author of a thesis to distil poetry from it; but the field is not one devoid of emotion, and in her poem Dr Palmlund portrays the scene as many have experienced it.

\section{THE ESTROGEN PLAY}

Enter from Right

$P$ in gorgeously expensive garb, followed by

$M$ in white. Both men,

in vantage.

In proud and praising language

they vaunt the benefits of an invented drug,

the mimicry of what makes women want to

love

and bear children

Both do gain in fame and fortune. They will

do well

by the drug, do Good

and gain yet more in fame and fortune.

The stage is full of women searching

love

fertility and femininity.

Later, some weeks or lunar cycles or many year later.

Center stage: a group of women.

They suffer. They are

diseased, dying, dead.

Around them families bereft,

and other women fearful, accusing.

The audience aroused

by pity for the victims and by fear

for their own lives.

They call for judgement and

preventive action. 
They want to know the truth.

They want to stop the harmful practice.

And then the explanations start:

the bodycounts, the rhetoric,

the fugues and subterfuges

the statements and the counterstatements,

the wallowing in scientific jargon, the defensive

chiding of reality.

The unwanted agression

and the sadness.

The anger over games and trickery.

The anxiety,

the doubts,

the greed, the injured

vanity.

The chorus, loud,

comments,

laments

and blames.

Where are the gods

descending from above

to restore harmony?

The arbiters (in gray) react,

but slowly.

They are machine gods

They blandly pass their judgement to appease

the audience.

The chorus then reverts to silence.

What is the play about?

The struggle over power

and control: who decides

to do what to whom

and why?

The actors caught in roles,

the roles defined by settings,

each actor moving in a web of power, each with but a narrow interval of free choice.

The battle over morals:

whether 'tis better to produce and sell and to control,

than to prevent uncertain harm and...

The human sacrifice

in order to promote the interests

of those in dominance.

Ingar Palmlund 